\title{
Herpes zoster surveillance using electronic databases in the Valencian Community (Spain)
}

\author{
Nuria Morant-Talamante, Javier Diez-Domingo*, Sergio Martínez-Úbeda, Joan Puig-Barberá, Sara Alemán-Sánchez \\ and Lina Pérez-Breva
}

\begin{abstract}
Background: Epidemiologic data of Herpes Zoster (HZ) disease in Spain are scarce. The objective of this study was to assess the epidemiology of $\mathrm{HZ}$ in the Valencian Community (Spain), using outpatient and hospital electronic health databases.

Methods: Data from 2007 to 2010 was collected from computerized health databases of a population of around 5 million inhabitants. Diagnoses were recorded by physicians using the International Classification of Diseases, 9th Revision, Clinical Modification (ICD-9-CM). A sample of medical records under different criteria was reviewed by a general practitioner, to assess the reliability of codification.
\end{abstract}

Results: The average annual incidence of HZ was 4.60 per 1000 persons-year (PY) for all ages (95\% Cl: 4.57-4.63), is more frequent in women [5.32/1000PY (95\% Cl: 5.28-5.37)] and is strongly age-related, with a peak incidence at 70-79 years. A total of 7.16/1000 cases of $\mathrm{HZ}$ required hospitalization.

Conclusions: Electronic health database used in the Valencian Community is a reliable electronic surveillance tool for $\mathrm{HZ}$ disease and will be useful to define trends in disease burden before and after $\mathrm{HZ}$ vaccine introduction.

Keywords: Herpes Zoster, Epidemiology, Electronic health record, Spain

\section{Background}

Herpes Zoster (HZ; shingles) results from the reactivation of Varicella-Zoster Virus (VZV) that has been latent in the spinal and cranial sensory ganglia after primary infection with varicella (chickenpox), usually during childhood [1]. A vesicular skin rash in the affected dermatome, commonly accompanied by acute pain, characterizes the acute phase of $\mathrm{HZ}$ disease.

Approximately $14 \%$ of all patients with shingles will develop complications [2]. The most common and weakening is postherpetic neuralgia (PHN), defined by most investigators as pain being present at 90 days after the rash appears $[1,2]$. Both the acute pain associated with $\mathrm{HZ}$ and PHN have a negative impact on healthrelated quality of life, interfering significantly with physical, emotional, and social functioning [3-6], and quantitatively similar to congestive heart failure, severe

\footnotetext{
*Correspondence: diez_jav@gva.es

Vaccine Research Area, Foundation for the Promotion of Health and Biomedical Research in the Valencian Region FISABIO - Public Health, Valencia, Spain
}

(c) 2013 Morant-Talamante et al.; licensee BioMed Central Ltd. This is an open access article distributed under the terms of the Creative Commons Attribution License (http://creativecommons.org/licenses/by/2.0), which permits unrestricted use, distribution, and reproduction in any medium, provided the original work is properly cited. diabetes [7].

The risk of $\mathrm{HZ}$ and its complications increases with advancing age, being more manifest in persons over $50-60$ years of age $[1,2,8,9]$. Among individuals who reach age 85 years of age, approximately $50 \%$ will have experienced at least one episode of $\mathrm{HZ}$ [10]. The incidence of acute $\mathrm{HZ}$ in the European general population ranges between 2.0-4.8 per 1000 persons-year (PY) for all ages, and increases after age 50 years to around 7-8/ 1000 PY [11,12]. Over the coming decades, Europe's demographic patterns will change dramatically, and it is expected that our populations will become older than ever before [13]. This suggests that the incidence of $\mathrm{HZ}$ could vary in relation to an older population, possibly as a result of immunosenescence [14].

Several studies support the hypothesis that exposure to childhood varicella reduces the risk of developing $\mathrm{HZ}$ by boosting specific immunity to VZV [15-19]. Based on this hypothesis, mathematical models suggest that a successful childhood vaccination program may decrease the 
circulation of wild-type VZV, and therefore the stimulation of cellular immunity that could prevent the occurrence of shingles in the adult population [20-23]. This could have significant public health consequences, if a universal mass VZV vaccination program is implemented in childhood. Although this issue is still controversial and there is no firm evidence that this increase will occur [24-26], monitoring of disease trends over time will help understand the impact of different factors upon the incidence of HZ. In the Valencian Community (Spain), varicella vaccination is recommended and funded at 12 years of age in those subjects who have not been in clear contact with the virus. This helps avoid severe cases in adults with no impact upon circulation of the virus. About $30 \%$ of toddlers also receive the vaccine after their pediatrician's recommendation [27]. With this low coverage figure, the virus is circulating within the population and no effect upon HZ is expected.

The efficacy of a live attenuated zoster vaccine, Zostavax $^{\circ}$, in preventing $\mathrm{HZ}$ and PHN has been tested in adults $\geq 60$ years of age, yielding efficacy rates of $51 \%$ and $67 \%$, respectively [28], and of $70 \%$ for incident $\mathrm{HZ}$ in subjects aged 50-59 years old [29]. In a recent population-based study of 766,330 individuals aged $\geq 65$ years, the effectiveness was seen to be $48 \%$ [30]. This vaccine is generally well tolerated, has been licensed in the European Union in 2006 for people aged $\geq 50$ years [31], and is expected to be widely used in Spain over the next few years. Another adjuvanted vaccine is under development [32-34].

In Spain, $\mathrm{HZ}$ is presently not a notifiable disease, and epidemiological data are scarce. A recent prospective study in the Valencian Community (Spain) showed an HZ incidence of 4.1 per 1000 persons > 14 years of age during 2007 [35,36]. Reliable epidemiological data are needed before any universal recommendation of $\mathrm{HZ}$ vaccines can be made, in order to assess the impact of $\mathrm{HZ}$ vaccination. The purpose of this study was to explore the epidemiology of $\mathrm{HZ}$ in the Valencian Community during a four-year period (January 2007 to December 2010), and to estimate the reliability of the regional electronic medical database for epidemiological studies, with a view to creating surveillance tools for future and efficient assessments of $\mathrm{HZ}$ incidence in the post-HZ vaccine era.

\section{Methods}

\section{Setting and study population}

The Valencian Community, in the east of Spain, has a population of 5,117,190 inhabitants (2011) [37], and over $98 \%$ are covered by the national public health system (NHS) [38]. Primary care visits and hospitalizations are recorded in clinical databases. Using these, we sought cases of $\mathrm{HZ}$ of all ages and both sexes attended in the
NHS from 1 January 2007 to 20 December 2010. From each HZ case we obtained all medical visits, prescriptions and demographic data.

\section{Abucasis electronic healthcare database}

The Abucasis electronic medical database was implemented in the Valencian Community for outpatient and primary care settings in 2006, and offers the possibility of linking patient care and public health [39]. From 2006 to 2010 (when the whole health system was computerized), the percentage of the population included in Abucasis increased from $73.1 \%$ in 2007 to $88.8 \%$ in 2008 and $95.7 \%$ in 2009 (Abucasis managers, personal communication). Abucasis contains an ambulatory information system called SIA, which registers any medical contact (visit), and the attending physician uses a dropdown menu with the International Classification of Diseases, 9th Revision, Clinical Modification (ICD9-CM) to record diagnoses. Abucasis also links other databases: Care Provision Management (GAIA), which is the drug information system available to the different professionals involved in prescription and dispensation, addressed from the Department of Health; and the Vaccine Information System (RVN) [40]. Other databases used in this study, such as the Hospital Data Surveillance System (CMBD), are described elsewhere [41] and can be linked through a unique personal identification number (SIP), for the collection of demographic data.

\section{Case definition}

For the identification of incident cases of $\mathrm{HZ}$, we searched SIA for any subject with first appearance of an HZ-related ICD-9-CM code (all ICD-9-CM 053 codes: $\mathrm{HZ}$ or $\mathrm{HZ}$ related complications), and the CMBD database for an $\mathrm{HZ}$ diagnosis in any position (1st to 9th). GAIA was searched for information on all subjects who were prescribed antiviral drugs (acyclovir, famcyclovir or valacyclovir) at doses only licensed for use in $\mathrm{HZ}$ by the Spanish Medicines Agency (AEMPS).

Any outpatient medical contact or visit, hospital admission or electronic prescription related to $\mathrm{HZ}$ was considered as a medical encounter. In order to avoid an overestimation of results, and in an attempt to identify recurrent $\mathrm{HZ}$ episodes, each medical encounter not preceded by another encounter in the last six months, and succeeded by another encounter in the following three months was considered as a recurrent $\mathrm{HZ}$ case.

To assess data quality, a total of 550 medical records were reviewed by a physician (NMT) in order to assess coding reliability and the accuracy of the filters used. These medical records were randomly selected after request of the following criteria: definition of incident $\mathrm{HZ}$ case and recurrent $\mathrm{HZ}$ case (300 records reviewed), prescription of specific topical and oral $\mathrm{HZ}$ antiviral drugs 
without a specific HZ ICD-9-CM code (100 records reviewed), discordance of the narrative diagnostic description with the assigned ICD-9-CM HZ code (100 records reviewed), and hospitalizations with an $\mathrm{HZ}$ diagnosis not appearing in the Abucasis database (50 records reviewed). In order to determine recurrence, each medical contact in the Abucasis database from 1 June 2006 to 31 March 2011 was evaluated. Confirmation of an $\mathrm{HZ}$ diagnosis required an HZ ICD-9-CM code in addition to application of at least one of the following criteria:

1. Detailed physician description of characteristic HZ skin lesions

2. Prescription of antiviral drugs

3. Temporary disability under HZ diagnosis

4. Referral for specialist assessment due to $\mathrm{HZ}$ disease, without a subsequent diagnostic exclusion of $\mathrm{HZ}$ diagnosis

Our data from 2007 were graphed together with the results obtained in a regional prospective cohort study in patients aged $>14$ years and carried out in 25 primary care settings in the Valencian Community during the same year $[35,36]$.

All databases were merged using the database manager MySQL 5.1. The random selection for quality control of coding was performed using its "rand" function. Analyses were performed using MySQL and Epidat 3.1. We calculated annual incidence rates of $\mathrm{HZ}$ by dividing the number of cases by the persons registered in SIP in each year. The exact $95 \%$ confidence interval (CI) for the incidence rates was calculated on the basis of a normal distribution. The Risk Ratio was calculated to assess differences between males and females.

\section{Ethical considerations}

The study protocol abided with the principles of the Declaration of Helsinki and was approved by the Public Health Ethics Committee of Valencia. Waiver of informed consent was accepted for medical history review.

\section{Results}

\section{$\mathrm{HZ}$ case confirmation}

We identified a total of 85,586 persons in SIA and/or CMBD with a first diagnosis of HZ. Our criteria of recurrence were met by 3300 of them. After chart review, the positive predictive value (PPV) for $\mathrm{HZ}$ case definition was $92.7 \%$ (95\% CI 89.1-95.4), and for recurrent HZ cases was $55.1 \%$ (95\% CI 47.0-63.0). Due to the low PPV of the recurrence filter, only the incident HZ cases were included in our estimations.

The PPV for HZ diagnosed only by high-dose antiviral prescription was $26 \%$ (95\% CI: 17.7-35.7), therefore, no case identified only by the prescription of antivirals was considered as an $\mathrm{HZ}$ case.

\section{Epidemiological analysis $\mathrm{HZ}$ incidence}

Over the four-year study period, we identified 85,586 persons with incident cases of $\mathrm{HZ}$ requiring medical care, which correspond to an incidence in all age groups of 4.60/1000 PY (95\% CI: 4.57-4.63). The figures remained rather constant over the years: 4.58/1000 PY (95\% CI: 4.51-4.65) in 2007, 4.89 (95\% CI: 4.83-4.95) in 2008, 4.67 (95\% CI: 4.61-4.73) in 2009, and 4.29 (95\% CI: 4.24-4.35) in 2010 (Figure 1).

HZ incidence rates were strongly aged-related, and more than half of the cases involved patients over 50 years of age $(63.18 \%)$ (Table 1$)$. The incidence in the non-pediatric age group ( $\geq 15$ years) was $5.02 / 1000$ PY (95\% CI: 4.99-5.06), while in the target population for $\mathrm{HZ}$ vaccine (adults aged $\geq 50$ years) the incidence was 8.60/1000 PY (95\% CI: 8.53-8.67). This trend was maintained each year during the whole study period. An incidence peak was observed in those aged 70-79 years, with a maximum of $11.55 / 1000$ PY (95\% CI: 11.3211.79) in women and 9.41/1000 PY (95\% CI: 9.18-9.65) in men. A drop in incidence in the older age group occurred in the primary care database but was not seen in the hospitalizations (Table 2).

$\mathrm{HZ}$ was less common among men [3.86/1000 PY (95\% CI: 3.82-3.90)] than women $[5.32 / 1000 \mathrm{PY}(95 \%$ CI: 5.28-5.37)] in the total population, with a RR 0.73 (95 CI: 0.72-0.74) (Table 1).

A total of 1458 hospitalizations with HZ related ICD9-CM codes occurred during the study period (an annual average of 365 admissions). Of these, 683 were men (46.8\%) and 775 women (53.2\%). The mean age was 67.5 years (range 0-100). Characteristics referred to hospitalized population and hospitalization rates are shown in Tables 2 and 3.

HZ was the first coded diagnosis in 383 cases $(26.2 \%$ of all hospitalizations). For these cases, secondary codes were hypertension (7.8\%), hematopoietic malignancies (3.4\%), HIV infection (2.6\%), diabetes mellitus (2.3\%) and urinary tract infection (1.3\%). In $5.7 \%$ of the cases, $\mathrm{HZ}$ was the only diagnostic code. HZ was the second listed diagnosis in 250 admissions (17.1\%). For these cases, first coded diagnoses were respiratory tract infectious diseases (8\%), meningitis (6\%), HIV infection (6\%) and chronic obstructive pulmonary disease (2\%).

The most frequently coded HZ diagnosis was ICD-9 -CM 053.9 (HZ without complications) (Table 4). A total of 679 patients admitted to hospital with $\mathrm{HZ}$ as first listed diagnosis were not coded as a HZ case in SIA. Chart review of 50 of these patients showed the reasons for not coding to be death, change of address, lack of 


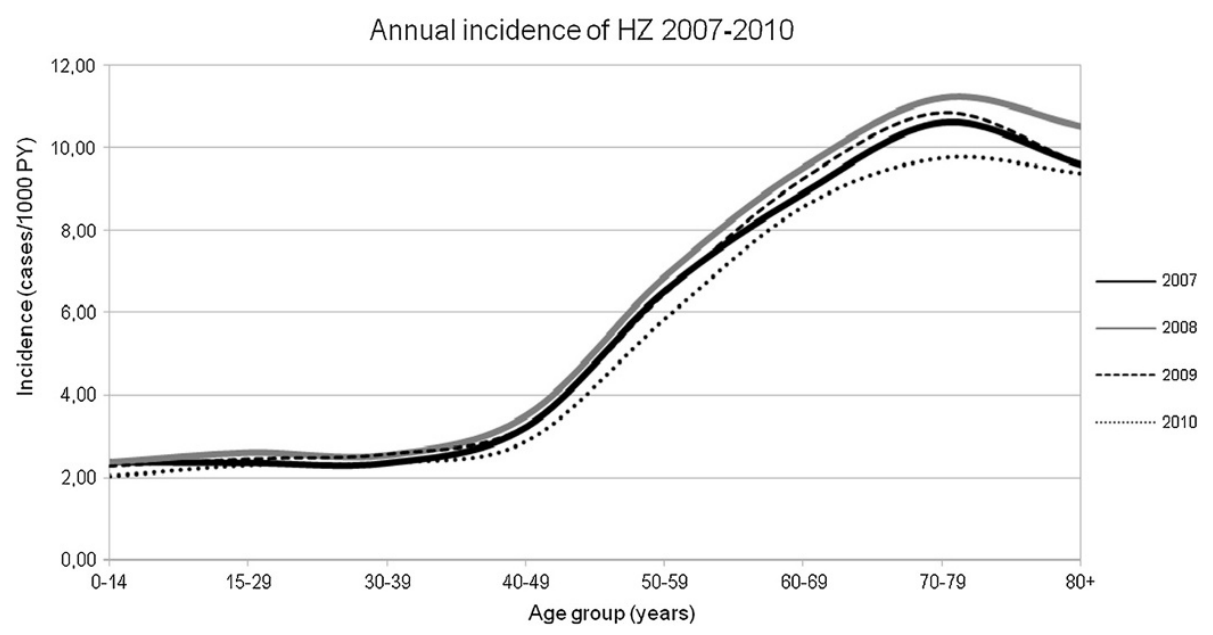

Figure 1 Incidence of HZ / 1000 person-years by age-groups, Valencian Community, Spain,years 2007-2010.

follow-up, or no HZ ICD-9-CM codification but mentioning hospitalization under other ICD-9-CM code.

Figure 2 depicts the age incidence in this study and in the prospective study [35]. In both studies the annual incidence was higher in females. The prospective study showed an incidence of 4.5/1000 PY (95\% CI: 3.5-5.4) in females and 2.7/1000 PY (95\% CI: 1.9-3.5) in males, while the electronic database showed an incidence of 5.32 (5.26-5.37) per 1000 PY for women and 3.86 (3.82-3.90) per 1000 PY for men (Table 1).

\section{Discussion}

In this study we used medical electronic databases from a region of Spain in order to reliably estimate $\mathrm{HZ}$ incidence. Our results showed an HZ incidence of 4.60/1000 PY, with a strong correlation to age, and with a drop in incidence in patients $\geq 80$ years of age, which was not observed in hospitalizations. Incidence rates were higher among women in most age groups, with an overall figure of 3.86 in males and 5.32 PER 1000 PY in females.

Epidemiological studies on HZ in Spain are scarce and are needed for future estimations of disease burden $[35,36,42,43]$. Our study used health databases that cover almost the entire population living in the Valencian Community, including hospitalizations and ambulatory patients. To the best of our knowledge, there is only one study of similar characteristics in Spain, conducted in Navarra (a northern region of the country) before systematic varicella vaccination [44].

One of the limitations of the study is that the Abucasis database was not developed for medical billing purposes, and this may imply the obtainment of less detailed information. Although ICD-9-CM codes are routinely used, general practitioners (GP) may be unaware of its importance. To overcome this, codification is performed in simple way - the system presenting a list of possible
ICD-9-CM codes after the diagnosis is written. In the case of Zoster, which is a common diagnosis, with no synonyms, ICD-9 coding is relatively easy. On the other hand, trained personnel codify CMBD. In order to assess the reliability of $\mathrm{HZ}$ codification, a random review of medical records showed good matching between ICD-9$\mathrm{CM}$ coding and a real episode of $\mathrm{HZ}$. A total of $7.7 \%$ of the reviewed notes with the diagnosis of Herpes Zoster did not meet the full requirements for being considered a case. Most of these situations were due to a lack of description of the lesions. We considered that most of these cases could be HZ, but the GP did not provide sufficient written details, possibly because of the great care burden found in primary care, which prevents entering detailed information in medical notes. This consequently may have understated $\mathrm{HZ}$ case confirmation.

For recurrent cases our temporal filters were not wholly suitable, and therefore the system did not allow for analysis of recurrent cases.

Another limitation is that emergency room visits and private medical visits were not included in any of the databases. Since the medication usually prescribed for $\mathrm{HZ}$ is expensive and is not subsidized in these situations, we assumed that only a minority of patients would not seek public medical care in order to receive subsidized drugs. As a population database study, it is possible that some individuals did not seek medical care. Another limitation to be taken into account is that we only included clinical diagnoses of $\mathrm{HZ}$, since laboratory confirmation of $\mathrm{HZ}$ is rarely used in normal clinical practice.

Due to bureaucratic problems, SIA data for the year 2010 were given until 20 December. We assume that the remaining 11 days would have no significant impact upon our estimations.

On comparing results corresponding to 2007 from the Abucasis database and a prospective study carried out in 
Table 1 Annual incidence rate (2007-2010) for HZ per 1000 PY (adjusted population*) per age-group in the Valencian Community (Spain)

\begin{tabular}{|c|c|c|c|c|c|c|c|c|c|c|}
\hline \multirow[b]{2}{*}{$\begin{array}{l}\text { Age } \\
\text { group } \\
\text { (years) }\end{array}$} & \multicolumn{2}{|c|}{2007} & \multicolumn{2}{|c|}{2008} & \multicolumn{2}{|c|}{2009} & \multicolumn{2}{|c|}{2010} & \multirow{2}{*}{$\begin{array}{l}2007-2010 \\
\text { MALES } \\
\text { Incidence } \\
(95 \% \mathrm{Cl})\end{array}$} & \multirow{2}{*}{$\begin{array}{c}2007-2010 \\
\text { FEMALES } \\
\text { Incidence } \\
(95 \% \mathrm{Cl})\end{array}$} \\
\hline & $\begin{array}{c}\text { Cases } \\
\text { (Population) }\end{array}$ & $\begin{array}{c}\text { Incidence } \\
(95 \% \mathrm{Cl})\end{array}$ & $\begin{array}{c}\text { Cases } \\
\text { (Population) }\end{array}$ & $\begin{array}{c}\text { Incidence } \\
(95 \% \mathrm{CI})\end{array}$ & $\begin{array}{c}\text { Cases } \\
\text { (Population) }\end{array}$ & Incidence & $\begin{array}{c}\text { Cases } \\
\text { (Population) }\end{array}$ & $\begin{array}{l}\text { Incide } \\
(95 \%\end{array}$ & & \\
\hline $0-14$ & $1324(561405)$ & $2.36(2.23-2.49)$ & $1638(690421)$ & $2.37(2.26-2.49)$ & 1715 (762629) & $2.25(2.14-2.36)$ & $1610(800131)$ & $2.01(1.91-2.11)$ & $2,12(2.04-2.19)$ & $2.36(2.27-2.44)$ \\
\hline $15-29$ & 1702 (727512) & $2.34(2.23-2.45)$ & 2246 (859724) & $2.61(2.50-2.72)$ & 2219 (912691) & $2.43(2.33-2.53)$ & 2077 (914068) & $2.27(2.17-2.37)$ & $2,26(2.19-2.34)$ & $2,57(2.49-2.65)$ \\
\hline 30-39 & $1548(663307)$ & $2.33(2.22-2.45)$ & 2051 (804937) & $2.55(2.44-2.66)$ & 2271 (890097) & $2.55(2.45-2.66)$ & $2156(923521)$ & $2.33(2.24-2.4)$ & $2,19(2.12-2.26)$ & $2.72(2.64-2.80)$ \\
\hline $40-49$ & 1796 (558784) & $3.21(3.07-3.36)$ & 2401 (685727) & $3.50(3.36-3.64)$ & 2460 (761831) & $3.23(3.10-3.36)$ & 2299 (804414) & $2.86(2.74-2.97)$ & $2,68(2.59-2.76)$ & $3,72(3.62-3.82)$ \\
\hline-59 & $2782(426382)$ & $6.52(6.28-6.77)$ & 3586 (521416) & $6.88(6.65-7.10)$ & 3732 (579549) & $6.44(6.23-6.65)$ & $3630(621615)$ & $5.84(5.65-6.03)$ & $4,85(4.72-4.99)$ & $7,87(7.70-8.04)$ \\
\hline 60-69 & 3200 (359492) & 8.90 (8.59-9.21) & 4145 (435089) & $9.53(9.24-9.82)$ & 4534 (489996) & 9.25 (8.99-9.52) & 4414 (514783) & $8.57(8.32-8.83)$ & $7.73(7.54-7.91)$ & $10.26(10.05-10.46)$ \\
\hline 70-79 & 3235 (304607) & $10.62(10.26-10.98)$ & 4026 (359151) & $11.21(10,87-11.55)$ & 4188 (385600) & 10.86 (10.53-11.19) & 3939 (403616) & $9.76(9.46-10.06)$ & $9.41(9.18-9.65)$ & $11.55(11.32-11.79)$ \\
\hline$\geq 80$ & 1718 (179060) & $9.59(9.14-10.05)$ & 2265 (215358) & $10.52(10.09-10.95)$ & 2331 (242269) & $9.62(9.23-10.01)$ & 2348 (250391) & $9.38(9.00-9.75)$ & $9.55(9.21-9.89)$ & $9.88(9.27-10.14)$ \\
\hline Total & 17305 (3780550) & $4.58(4.51-4.65)$ & $22358(4571822)$ & $4.89(4.83-4.95)$ & $23450(5024661)$ & $4.67(4.61-4.73)$ & $22473(5232539)$ & $4.29(4.24-4.35)$ & $3.86(3.82-3.90)$ & $5.32(5.26-5.37)$ \\
\hline
\end{tabular}

*Adjusted population: Correction factor 73.09\% (2007), 88.75\% (2008), 95.72\% (2009), 100\% (2010). 
Table 2 Hospitalizations due to Herpes Zoster by age-groups in the Valencian Community (Spain), $2007-2010$

\begin{tabular}{|c|c|c|c|c|c|c|}
\hline Age group (years) & Population & Cases & Incidence * & $95 \% \mathrm{Cl}$ & Total $\mathrm{HZ}$ cases in the population & Hospitalization rates** \\
\hline $0-14$ & $3,142,807$ & 40 & 1.27 & $0.88-1.67$ & 6287 & 6.36 \\
\hline $15-29$ & $3,831,527$ & 22 & 0.57 & $0.33-0.81$ & 8244 & 2.67 \\
\hline $30-39$ & $3,667,802$ & 47 & 1.28 & $0.92-1.65$ & 8026 & 5.86 \\
\hline $40-49$ & $3,137,382$ & 49 & 1.56 & $1.12-2.00$ & 8956 & 5.47 \\
\hline $50-59$ & $2,397,883$ & 52 & 2.17 & $1.58-2.76$ & 13730 & 3.79 \\
\hline $60-69$ & $2,008,718$ & 91 & 4.53 & $3.60-5.46$ & 16293 & 5.60 \\
\hline $70-79$ & $1,627,844$ & 156 & 9.58 & $8.08-11.09$ & 15388 & 10.14 \\
\hline $80+$ & 991,106 & 156 & 15.74 & $13.27-18.21$ & 8662 & 18.01 \\
\hline Total & $20,805,069$ & 613 & 2.95 & $2.71-3.18$ & 85586 & 7.16 \\
\hline
\end{tabular}

*Cases per 100,000 person-years.

**Hospitalization rates (number of hospitalizations per 1000 cases of $\mathrm{HZ}$ ).

a similar population ( $>14$ years) [35,36], the incidence figures were found to be similar, being slightly higher when using the electronic database (5.0/1000 PY versus 4.1/1000 PY). These differences mainly occurred in two age groups (15-49 and 60-69 years), and as the authors point out [35], this may reflect their low precision. The study conducted in Navarra [42] showed a mean HZ incidence of 4.25/1000 PY during 2005-2006.

The number of hospitalizations in our study was lower than in similar retrospective Spanish studies during the previous study period [41,42]. In one of these studies [41], differences were found among the Spanish autonomous communities, with lower incidence rates in the Valencian Community. To confirm the reliability of our data, we compared them with the national data for the same study period (data not shown), and found both figures to be the same, with a decrease in the incidence of HZ hospitalization over time, possibly due to changes in admission criteria, to greater awareness among physicians of the need for early antiviral treatment, or to changes in coding practices. However, similar hospitalizations rates were found $(2.69 / 100,000$ PY) in another Spanish study using the CMBD database for the study period 1997-2004 [45].

As in other epidemiological studies, the incidence of $\mathrm{HZ}$ is strongly sex- and age-related, with higher incidences in women over 50 years. Our incidence was slightly higher than in other European studies using electronic databases. In France, the yearly $\mathrm{HZ}$ incidence rate for all ages averaged 3.82/1000 PY in the study period 2005-2008 [46], while in Italy a retrospective study showed an incidence of 4.31/1000 PY for population aged 15 years or older during the three-year study period (2003-2005) [47]. Another study conducted in the Netherlands during 1994-1999, calculated an HZ incidence of 3.4/1000 PY [48]. A similar German study performed in an older population $(\geq 50$ years) reported higher figures (9.60/1000 PY during 20072008) [49]. We found similar rates in the United States: 4.4/1000 PY for all ages during 2006 [50]. Apart from the fact that the results of different descriptive epidemiological

Table 3 Characteristics of hospitalizations due to Herpes Zoster in the Valencian Community (Spain) 2007-2010

\begin{tabular}{|c|c|c|c|c|c|}
\hline Hospital admissions & 2007 & 2008 & 2009 & 2010 & Total \\
\hline \multicolumn{6}{|c|}{ Discharges with 1st-9th listed HZ related ICD-9-CM code } \\
\hline Number of admissions & 325 & 395 & 334 & 401 & 1458 \\
\hline Median age (years) (min-max) & $66.67(1-95)$ & $67.64(0-97)$ & $66.47(0-100)$ & $68.94(1-99)$ & $67.51(0-100)$ \\
\hline Men/Women & $155 / 173$ & $172 / 223$ & $152 / 182$ & $201 / 200$ & $680 / 778$ \\
\hline Sex ratio $(M / W)$ & 0.89 & 0.77 & 0.83 & 1.01 & 0.87 \\
\hline Average length of stay (days) (SD) & $10.56(11.43)$ & $10.12(12.01)$ & $9.82(10.63)$ & $8.65(8.29)$ & $9.75(10.67)$ \\
\hline \multicolumn{6}{|c|}{ Discharges with 1st-2nd listed HZ related ICD-9-CM code } \\
\hline Number of admissions & 135 & 153 & 136 & 189 & 613 \\
\hline Median age (years) (min-max) & $60.19(1-95)$ & $62.49(0-93)$ & $60.19(0-97)$ & $65.50(1-97)$ & $62.44(0-97)$ \\
\hline Men/Women & $61 / 74$ & $73 / 80$ & $63 / 73$ & 98/91 & $295 / 318$ \\
\hline Sex ratio $(M / W)$ & 0.82 & 0.91 & 0.86 & 1.08 & 0.93 \\
\hline Average length of stay (days) (SD) & $7.73(6.78)$ & $7.98(7.69)$ & $7.15(5.93)$ & $7.47(5.96)$ & $7.59(6.61)$ \\
\hline
\end{tabular}


Table 4 Number of Herpes Zoster - related medical encounters (visits) and proportion of HZ diagnoses (ICD-9-CM codes), 2007-2010

\begin{tabular}{|c|c|c|c|}
\hline \multirow[t]{3}{*}{ ICD-9-CM codes (Description) } & \multicolumn{3}{|c|}{ Number of medical visits (proportion \%) } \\
\hline & \multicolumn{2}{|c|}{ Hospital admissions } & \multirow[t]{2}{*}{ Outpatient $^{*}$} \\
\hline & ICD-9-CM1st-9th & $I C D-9-C M 1 \mathrm{st}-2 \mathrm{nd}$ & \\
\hline 053.9 (Herpes zoster without complications) & $812(55.50)$ & $328(53.52)$ & $70816(36.93)$ \\
\hline 0.53 .19 (Herpes zoster with other nervous system complications) & $330(22.63$ & $94(14.85)$ & $3326(1.73)$ \\
\hline 053.79 (Herpes zoster with other specified complications) & $61(4.17)$ & $46(7.27)$ & $532(0.28)$ \\
\hline 053.20 (Herpes zoster with ophthalmic complications) & $51(3.49)$ & $28(4.42)$ & $7313(0.38)$ \\
\hline 053.29 (Herpes zoster with other ophthalmic complications) & $50(3.42)$ & $28(4.42)$ & $312(0.16)$ \\
\hline 053.12 (Postherpetic trigeminal neuralgia) & $45(3.08)$ & $20(3.16)$ & $4729(2.47)$ \\
\hline 053.13 (Postherpetic polyneuropathy) & $32(2.19)$ & $10(1.58)$ & $1821(0.95)$ \\
\hline 053.11 (Geniculate herpes zoster) & $29(1.98)$ & $19(3.02)$ & $496(0.26)$ \\
\hline 053.8 (Herpes zoster with unspecified complications) & $27(1.85)$ & $21(3.43)$ & $663(0.35)$ \\
\hline 053 (Herpes Zoster without specification) & 0 & 0 & 94950 (49.52) \\
\hline Other & $56(3.82)$ & $39(6.16)$ & $6778(3.54)$ \\
\hline Total (medical visits under HZ ICD-9-CM codes / number of patients) & $1463 / 1458$ & $633 / 613$ & $191736(85586)$ \\
\hline
\end{tabular}

Outpatient: * includes HZ ICD-9-CM codifications (053.0-053.9) for all medical visits.

studies are highly dependent upon the methodology used, some of these studies included emergency room visits, and some countries use ICD-9-CM for billing purposes, which would result in variable incidence rates.

Higher incidence rates were found in the placebo controls of clinical trials in the $\geq 60$ years age group, specifically $13.00 / 1000$ PY $[50,51]$ or $11.12 / 1000$ PY [28], which indicates that an active search of HZ cases considerably increases their incidence.

Our incidence peaked at 70-79 years of age and decreased thereafter, especially in the $\geq 95$ years age group (data not shown). This drop in incidence was not seen in hospitalizations (Table 3). There are several explanations for this. Firstly, there could be a gradually reduced risk of $\mathrm{HZ}$, explained by the hypothesis that exposure to
VZV provides the host with progressive immunity to VZV reactivation [52,53]. Secondly, large proportions of subjects in this age group have disabilities or walking difficulties, and consequently are usually visited by family physicians at home. These visits are commonly not recorded in the Abucasis database, and medical prescriptions are handwritten. On the other hand, many of these patients live with relatives and usually move to other provinces outside our study area during part of the year, without unsubscribing from the Abucasis database; a potential $\mathrm{HZ}$ case therefore could have been registered elsewhere and not be counted as an incident case.

$\mathrm{HZ}$ incidence is age-related. This correlation could be explained by the progressive decline in VZV cell-

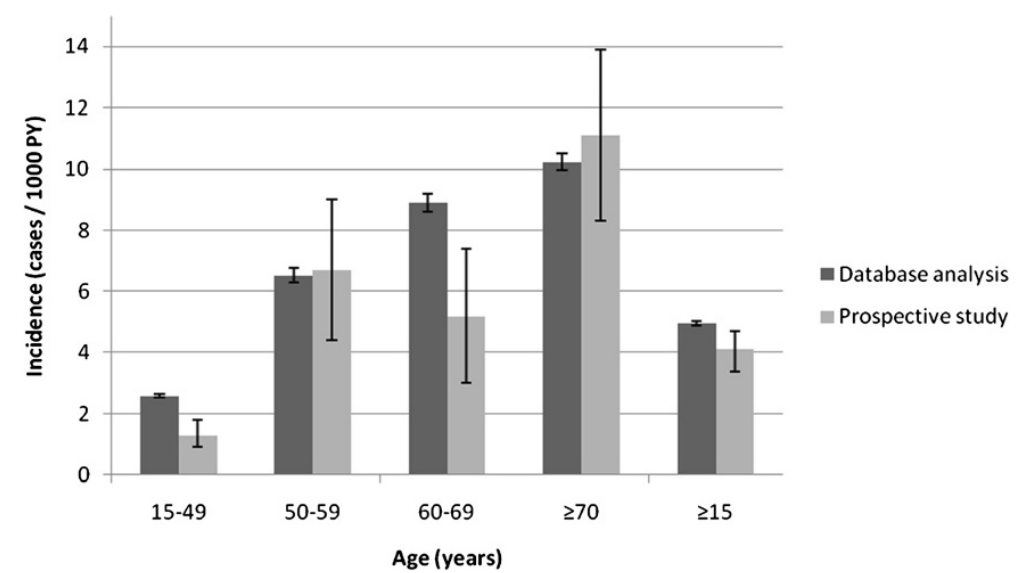

Figure 2 Description of the incidence of $\mathrm{HZ}$ per 1000 person-year by age $(95 \% \mathrm{Cl})$ in this study and in a prospective study in Valencia [35]. 
mediated immunity related to aging. The incidence should increase in a progressively aging population, which would imply a greater burden and cost of disease. Determinants of direct costs of an $\mathrm{HZ}$ episode are usually related to the prescription of antiviral drugs and repetitive primary care visits in the case of PHN. Direct outpatient costs in several European countries average between $72.05 €$ and $247 €$ [36,54-56].

\section{Conclusions}

Our study confirms electronic databases as a reliable epidemiological tool for estimating the incidence of $\mathrm{HZ}$ disease. They provide an important source of information on the incidence of $\mathrm{HZ}$, which can be useful to define trends in disease burden before and after $\mathrm{HZ}$ vaccine introduction.

\section{Abbreviations}

HZ: Herpes Zoster; PHN: Postherpetic neuralgia; PY: Persons-year; NHS: National health system; SIA: Sistema de información ambulatoria (Ambulatory Information System); ICD-9-CM: International classification of diseases 9th revision, clinical modification; CMBD: Conjunto Mínimo Básico de Datos (Hospital Data Surveillance System); PPV: Positive predictive value; SPS: Shingles prevention study; VZV: Varicella-zoster virus; GP: General practitioner.
\end{abstract}

\section{Competing interests}

JDD Is acting as national coordinator and principal investigators for clinical studies and receiving funding from non-commercial funding bodies as well as commercial sponsors (Novartis Vaccines, GlaxoSmithKline, Baxter, Sanofi Pasteur MSD, Medlmmune, and Pfizer Vaccines) conducted on behalf of CSISP-FISABIO. He served as a as a board member for GSK, and received payment for lectures from SP-MSD, Novartis and Baxter that included support for travel and accommodation for meetings.

JPB Is acting as national coordinator and principal investigators for clinical studies and receiving funding from non-commercial funding bodies as well as commercial sponsors (Novartis Vaccines, GlaxoSmithKline and SanofiPasteur) conducted on behalf of CSISP-FISABIO. He served as a as a board member for GSK, and received payment for lectures that included support for travel and accommodation for meetings.

Other authors declare no conflict of interest.

\section{Authors' contributions}

NMT, JDD and JPB designed the study. SMU analyzed the data and performed the statistical analysis. NMT wrote the manuscript and reviewed clinical records. JDD coordinated the study. SAS, LPB, JDD and JPB provided valuable insight for revising the manuscript. All authors read and approved the final manuscript.

\section{Acknowledgements}

We thank Maria Alejandra Rodriguez-Galán and Silvia Pérez-Vilar for critical input to our paper.

Received: 25 March 2013 Accepted: 18 September 2013 Published: 5 October 2013

\section{References}

1. Johnson RW: Herpes zoster and postherpetic neuralgia. Expert Rev Vaccines 2010, 9(3 Suppl):21-26.

2. Johnson RW, McElhaney J: Postherpetic neuralgia in the elderly. Int J Clin Pract 2009, 63(9):1386-1391.

3. Drolet M, Brisson M, Schmader KE, Levin MJ, Johnson R, Oxman MN, et al: The impact of herpes zoster and postherpetic neuralgia on healthrelated quality of life: a prospective study. CMAJ 2010, 182(16):1731-1736.

4. Dworkin RH, Gnann JW, Oaklander AL, Raja SN, Schmader KE, Whitley RJ: Diagnosis and assessment of pain associated with herpes zoster and postherpetic neuralgia. J Pain 2008, 9(1 Suppl 1):S37-S44.
5. Drolet M, Levin MJ, Schmader KE, Johnson R, Oxman MN, Patrick D, et al: Employment related productivity loss associated with herpes zoster and postherpetic neuralgia: a 6-month prospective study. Vaccine 2012, 30(12):2047-2050.

6. Lukas K, Edte A, Bertrand I: The impact of herpes zoster and post-herpetic neuralgia on quality of life: patient-reported outcomes in six European countries. Z Gesundh Wiss 2012, 20(4):441-451.

7. Plotkin SAOW, Offit PA: Vaccines. 5th edition. Philadelphia: Saunders Elsevier; 2008.

8. Yawn BP, Saddier P, Wollan PC, St Sauver JL, Kurland MJ, Sy LS: A population-based study of the incidence and complication rates of herpes zoster before zoster vaccine introduction. Mayo Clin Proc 2007, 82(11):1341-1349.

9. Drolet M, Oxman MN, Levin MJ, Schmader KE, Johnson RW, Patrick D, et al: Vaccination against herpes zoster in developed countries: state of the evidence. Hum Vaccin Immunother 2013, 9(5):1177-1184.

10. Schmader K: Herpes zoster in older adults. Clin Infect Dis 2001, 32(10):1481-6.

11. Pinchinat S, Cebrián-Cuenca AM, Bricout H, Johnson RW: Similar herpes zoster incidence across Europe: results from a systematic literature review. BMC Infect Dis 2013, 13:170.

12. Thomas SL, Hall AJ: What does epidemiology tell us about risk factors for herpes zoster? Lancet Infect Dis 2004, 4(1):26-33.

13. European Commission: Europe's demographic future: Facts and figures on challenges and opportunities. Directorate-General for Employment, Social Affairs and Equal Opportunities; 2012. http://ec.europa.eu/social/BlobServlet? docld=1540\&langld=en.

14. Aw D, Silva $A B$, Palmer DB: Immunosenescence: emerging challenges for an ageing population. Immunology 2007, 120(4):435-46.

15. Salleras M, Domínguez A, Soldevila N, Prat A, Garrido P, Torner N, et al: Contacts with children and young people and adult risk of suffering herpes zoster. Vaccine 2011, 29(44):7602-5.

16. Thomas SL, Wheeler JG, Hall AJ: Contacts with varicella or with children and protection against herpes zoster in adults: a case-control study. Lancet 2002, 360(9334):678-82.

17. Yih WK, Brooks DR, Lett SM, Jumaan AO, Zhang Z, Clements KM, et al: The incidence of varicella and herpes zoster in Massachusetts as measured by the behavioral risk factor surveillance system (BRFSS) during a period of increasing varicella vaccine coverage, 1998-2003. BMC Public Health 2005, 5:68.

18. Guzzetta G, Poletti P, Del Fava E, Ajelli M, Scalia Tomba GP, Merler S, et al: Hope-Simpson's progressive immunity hypothesis as a possible explanation for herpes zoster incidence data. Am J Epidemiol 2013, 177(10):1134-42

19. Bennett GJ, Watson CP: Herpes zoster and postherpetic neuralgia: past, present and future. Pain Res Manag 2009, 14(4):275-82.

20. Karhunen M, Leino T, Salo H, Davidkin I, Kilpi T, Auranen K: Modelling the impact of varicella vaccination on varicella and zoster. Epidemiol Infect 2010, 138(4):469-81.

21. Brisson M, Gay NJ, Edmunds WJ, Andrews NJ: Exposure to varicella boosts immunity to herpes-zoster: implications for mass vaccination against chickenpox. Vaccine 2002, 20(19-20):2500-7.

22. van Hoek AJ, Melegaro A, Zagheni E, Edmunds WJ, Gay N: Modelling the impact of a combined varicella and zoster vaccination programme on the epidemiology of varicella zoster virus in England. Vaccine 2011, 29(13):2411-20.

23. Gao Z, Gidding HF, Wood JG, Maclntyre CR: Modelling the impact of one-dose vs. two-dose vaccination regimens on the epidemiology of varicella zoster virus in Australia. Epidemiol Infect 2010, 138(4):457-68.

24. Gaillat J, Gajdos V, Launay O, Malvy D, Demoures B, Lewden L, et al: Does monastic life predispose to the risk of Saint Anthony's fire (herpes zoster)? Clin Infect Dis 2011, 53(5):405-10.

25. Poletti P, Melegaro A, Ajelli M, Del Fava E, Guzzetta G, Faustini L, et al: Perspectives on the impact of varicella immunization on herpes zoster. A model-based evaluation from three European countries. PLoS One 2013, 8(4):e60732.

26. Jumaan AO, Yu O, Jackson LA, Bohlke K, Galil K, Seward JF: Incidence of herpes zoster, before and after varicella-vaccination-associated decreases in the incidence of varicella, 1992-2002. J Infect Dis 2005, 191(12):2002-7.

27. Asociación Española de Pediatría: Documento en relación al calendario único de vacunaciones y las vacunas disponibles en España; 2013. 
http://vacunasaep.org/sites/vacunasaep.org/files/AEP-vacunas-y-calendariovacunal-unico_0.pdf.

28. Oxman MN, Levin MJ, Johnson GR, Schmader KE, Straus SE, Gelb LD, et al: A vaccine to prevent herpes zoster and postherpetic neuralgia in older adults. N Engl J Med 2005, 352(22):2271-84.

29. Schmader KE, Levin MJ, Gnann JW, McNeil SA, Vesikari T, Betts RF, et a: Efficacy, safety, and tolerability of herpes zoster vaccine in persons aged 50-59 years. Clin Infect Dis 2012, 54(7):922-8.

30. Langan SM, Smeeth L, Margolis DJ, Thomas SL: Herpes zoster vaccine effectiveness against incident herpes zoster and post-herpetic neuralgia in an older US population: a cohort study. PLoS Med 2013, 10(4):e1001420.

31. European Medicines Agency: European Public Assessment Report (EPAR) for ZOSTAVAX summary of product characteristics; 2012. http://www.ema.europa. eu/docs/en_GB/document_library/EPAR__Product_Information/human/ 000674/WC500053462.pdf

32. Study to Evaluate GSK Biologicals' Herpes Zoster Vaccine GSK1437173A in Adults Aged $>=70$ Years: ClinicalTrails.gov; 2012. http://Clinicaltrials.gov/ct2/ show/NCT01 165229?term=zoster\&rank=1.

33. Study to Evaluate GSK Biologicals' Herpes Zoster Vaccine GSK1437173A in Adults Aged > 50 Years: ClinicalTrials.gov; 2012. http://Clinicaltrials.gov/ct2/ show/NCT01165177?term=Zoster\&rank=14.

34. Leroux-Roels I, Leroux-Roels $G$, Clement F, Vandepapelière $P$, Vassilev $V$, Ledent $E$, et al: A phase $1 / 2$ clinical trial evaluating safety and immunogenicity of a varicella zoster glycoprotein e subunit vaccine candidate in young and older adults. J Infect Dis 2012, 206(8):1280-90.

35. Cebrián-Cuenca AM, Díez-Domingo J, Rodríguez MS, Puig-Barberá J, Navarro-Pérez J: Community' HZRGotV. Epidemiology of herpes zoster infection among patients treated in primary care centres in the Valencian community (Spain). BMC Fam Pract 2010, 11:33.

36. Cebrián-Cuenca AM, Díez-Domingo J, San-Martín-Rodríguez M, Puig-Barberá J, Navarro-Pérez J: Community HZRGotV. Epidemiology and cost of herpes zoster and postherpetic neuralgia among patients treated in primary care centres in the Valencian community of Spain. BMC Infect Dis 2011, 11:302.

37. Instituto Nacional de Estadística: Cifras oficiales de población resultantes de la revisión del Padrón municipal a 1 de enero de 2011; 2012. http:/www.ine.es/ jaxi/tabla.do?path $=/$ t20/e260/a2011/10/\&file=ccaa01.px\&type $=$ pcaxis\&L $=0$.

38. Indra Sistemas SA: Proyecto Abucasis Conselleria Sanitat Valencia; 2012. http://www.indracompany.com/sectores/sanidad/proyectos/179/proyectoabucasis-conselleria-de-sanitat-valencia.

39. España. Ministerio de Sanidad y Política Social: Las TIC en el Sistema Nacional de Salud: el programa Sanidad en línea: actualización de datos enero 2010. Madrid: Red.es; 2010:24. Available from: http:/www.msssi.gob.es/ profesionales/hcdsns/TICS/TICS_SNS_ACTUALIZACION_ES_2010.pdf.

40. Puig-Barberà J, Natividad-Sancho A, Calabuig-Pérez J, Lluch-Rodrigo JA, Pastor-Villalba E, Martínez-Úbeda S, et al: MF59-adjuvanted and virosomal influenza vaccines for preventing influenza hospitalization in older people: comparative effectiveness using the Valencia health care information system. Vaccine 2013, 31:3995-4002.

41. Gil A, Gil R, Alvaro A, San Martín M, González A: Burden of herpes zoster requiring hospitalization in Spain during a seven-year period (1998-2004). BMC Infect Dis 2009, 9:55

42. García Cenoz M, Castilla J, Montes Y, Morán J, Salaberri A, Elía F, et al Varicella and herpes zoster incidence prior to the introduction of systematic child vaccination in Navarre, 2005-2006. An Sist Sanit Navar 2008, 31(1):71-80

43. Pérez-Farinós N, Ordobás M, García-Fernández C, García-Comas L, Cañellas S, Rodero I, et al: Varicella and herpes zoster in Madrid, based on the sentinel general practitioner network: 1997-2004. BMC Infect Dis 2007, 7:59.

44. Gil A, San-Martín M, Carrasco P, González A: Epidemiology of severe varicellazoster virus infection in Spain. Vaccine 2004, 22(29-30):3947-3951.

45. Peña-Rey I, de Aragón MV M, Villaverde Hueso A, Terres Arellano M, Alcalde Cabero E, Suárez Rodríguez B: [Epidemiology of varicella in spain pre-and post-vaccination periods]. Rev Esp Salud Publica 2009, 83(5):711-24.

46. Chiappe SG, Sarazin M, Turbelin C, Lasserre A, Pelat C, Bonmarin I, et al: Herpes zoster: Burden of disease in France. Vaccine 2010, 28(50):7933-8.

47. Gialloreti LE, Merito M, Pezzotti P, Naldi L, Gatti A, Beillat M, et al: Epidemiology and economic burden of herpes zoster and post-herpetic neuralgia in Italy: a retrospective, population-based study. BMC Infect Dis 2010, 10:230.
48. de Melker $\mathrm{H}$, Berbers $\mathrm{G}$, Hahné $\mathrm{S}$, Rümke $\mathrm{H}$, van den Hof $\mathrm{S}$, de Wit $\mathrm{A}$, et al: The epidemiology of varicella and herpes zoster in The Netherlands: implications for varicella zoster virus vaccination. Vaccine 2006, 24(18):3946-52.

49. Ultsch B, Siedler A, Rieck T, Reinhold T, Krause G, Wichmann O: Herpes zoster in Germany: quantifying the burden of disease. BMC Infect Dis 2011, 11:173.

50. Leung J, Harpaz R, Molinari NA, Jumaan A, Zhou F: Herpes zoster incidence among insured persons in the United States, 1993-2006: evaluation of impact of varicella vaccination. Clin Infect Dis 2011, 52(3):332-40.

51. Tseng HF, Smith N, Harpaz R, Bialek SR, Sy LS, Jacobsen SJ: Herpes zoster vaccine in older adults and the risk of subsequent herpes zoster disease. JAMA 2011, 305(2):160-6.

52. Oxman MN: Herpes zoster pathogenesis and cell-mediated immunity and immunosenescence. J Am Osteopath Assoc 2009, 109(6 Suppl 2):S13-7.

53. Hope-Simpson RE: The Nature of Herpes Zoster: A long-term study and a new hypothesis. Proc $R$ Soc Med 1965, 58:9-20.

54. van Lier A, van Hoek AJ, Opstelten W, Boot HJ, de Melker HE: Assessing the potential effects and cost-effectiveness of programmatic herpes zoster vaccination of elderly in the Netherlands. BMC Health Serv Res 2010, 10:237.

55. Bilcke J, Ogunjimi B, Marais C, de Smet F, Callens M, Callaert K, et al: The health and economic burden of chickenpox and herpes zoster in Belgium. Epidemiol Infect 2012, 140(11):2096-109.

56. Scott FT, Johnson RW, Leedham-Green M, Davies E, Edmunds WJ, Breuer J: The burden of Herpes Zoster: a prospective population based study. Vaccine 2006, 24(9):1308-14.

doi:10.1186/1471-2334-13-463

Cite this article as: Morant-Talamante et al:: Herpes zoster surveillance using electronic databases in the Valencian Community (Spain). BMC Infectious Diseases 2013 13:463.

\section{Submit your next manuscript to BioMed Central and take full advantage of:}

- Convenient online submission

- Thorough peer review

- No space constraints or color figure charges

- Immediate publication on acceptance

- Inclusion in PubMed, CAS, Scopus and Google Scholar

- Research which is freely available for redistribution 